\title{
Severe hypercalcemia as an initial presenting manifestation of hepatocellular carcinoma
}

\author{
Michel William Ghobrial MD ${ }^{1}$, John George $M D^{2}$, Sunitha Mannam MD², \\ Samia R Henien $M^{3}$
}

MW Ghobrial, J George, S Mannam, SR Henien. Severe hypercalcemia as an initial presenting manifestation of hepatocellular carcinoma. Can J Gastroenterol 2002;16(9):607-609.

An 80-year-old white woman who presented with fatigue, weakness, weight loss, constipation and polydipsia is reported. The patient was given a diagnosis of severe hypercalcemia and was subsequently found to have clinical, roentgenographic and pathological evidence of hepatocellular carcinoma. Further studies revealed a low parathyroid hormone level, excluding the possibility of primary hyperparathyroidism, and a negative bone survey, precluding metastatic bone disease. The patient's hypercalcemia was believed to emanate from the humoral secretion of a parathyroid hormone-related peptide, which was found to be elevated, and was abated with conservative management while her cancer was being treated with chemotherapy. The details of this rarely documented presentation, which can easily be mistaken for hepatic encephalopathy, are provided.

Key Words: Hepatocellular carcinoma; Hypercalcemia

\section{Une hypercalcémie grave comme manifestation initiale de carcinome hépatocellulaire}

\begin{abstract}
RÉSUMÉ : On rend compte du cas d'une femme blanche de 80 ans qui s'est présentée parce qu'elle souffrait de symptômes de lassitude, de faiblesse, de perte de poids, de constipation et de polydipsie. La patiente a reçu un diagnostic d'hypercalcémie grave. On a ensuite découvert des observations cliniques, radiologiques et pathologiques de carcinome hépatocellulaire. Des études supplémentaires ont révélé un faible taux de parathormone, excluant la possibilité d'hyperparathyroïdie primaire, ainsi qu'une série osseuse négative, excluant la possibilité de métastases osseuses. On croit que l'hypercalcémie de la patiente émanait de la sécrétion humorale du peptide de la parathormone, qui était élevée et qui a été ramenée à un taux plus bas au moyen d'un traitement conservateur tandis que le cancer était traité par chimiothérapie. Les détails de cette présentation rarement documentée, qui peut être facilement confondue avec une encéphalopathie hépatique, sont fournis.
\end{abstract}

\footnotetext{
${ }^{1}$ Department of Medicine, Mercy Fitzgerald Hospital, Philadelphia; ${ }^{2}$ Department of Medicine, Mercy Catholic Medical Center, Philadelphia; ${ }^{3}$ Department of Medicine, Mercy Fitzgerald Hospital, Darby, Pennsylvania, USA

Correspondence and reprints: Dr Michel William Ghobrial, 772 Providence Road, \# B-402, Aldan, Pennsylvania 19018, USA.

Telephone/fax 610-284-6045, e-mail ghobrial@hotmail.com

Received for publication October 23, 2001. Accepted July 9, 2002
} 
$\mathrm{P}_{\mathrm{s}}^{\mathrm{r}}$ imary hepatocellular malignancy, while common in other parts of the world, is uncommon in the United States, accounting for only $1 \%$ to $2 \%$ of cancers at autopsy (1-3). Recent reports, however, have suggested an increasing frequency (4). These malignancies, frequently diagnosed late, are associated with underlying advanced liver disease with cirrhosis (5). Although the measurement of alpha-fetoprotein and ultrasound have been used as screening tools, their cost effectiveness is debatable (6-8).

The most common presenting manifestations are abdominal pain and liver masses $(9,10)$.

While a diversity of alterations in laboratory results can be observed in these patients, hypercalcemia is uncommon $(3,11)$. When hypercalcemia does occur, it is mainly caused by a local osteolytic effect of bone metastasis (12). Intrinsic hypercalcemia, caused by a humoral secretion from cancer cells and manifesting as the initial presentation of hepatocellular carcinoma, is extremely rare.

\section{CASE PRESENTATION}

An 80-year-old white woman presented with generalized weakness that had gradually worsened over a six-month period, constipation of two months' duration and poor appetite. Her medical history was significant for type 2 diabetes mellitus, hypertension and coronary artery disease, and she denied having abdominal pain, diarrhea, hematemesis or melena. She complained of polydipsia and polyuria with nocturia. The patient, who had experienced an unintentional weight loss of $25 \mathrm{~kg}$ over a six-month period, had no complaints of bony pains or recent fractures.

Her vital signs were normal. Other than mild pallor and dry mucous membranes, her head and neck examinations were normal. Heart and lung auscultations were essentially normal. Abdominal palpation revealed nontender hepatomegaly with an irregular texture and a hard consistency. The spleen was not felt. Results of a digital rectal examination were normal. There were no cutaneous manifestations of liver disease, and the breast examination was unremarkable. Other than generalized weakness, her neurological examination was unremarkable.

Complete blood count revealed a hemoglobin concentration of $97 \mathrm{~g} / \mathrm{L}$ (normal 120 to $160 \mathrm{~g} / \mathrm{L}$ ). White blood cell count and platelets were normal. Other than a blood sugar concentration of $7.18 \mathrm{mmol} / \mathrm{L}$ (normal 3.9 to $5.8 \mathrm{mmol} / \mathrm{L}$ ), the rest of her chemistry was unremarkable. Liver enzymes showed an aspartate aminotransferase concentration of $91 \mathrm{U} / \mathrm{L}$ (normal 10 to $41 \mathrm{U} / \mathrm{L}$ ), alanine aminotransferase $18 \mathrm{U} / \mathrm{L}$ (normal 5 to $49 \mathrm{U} / \mathrm{L}$ ), alkaline phosphatase $228 \mathrm{U} / \mathrm{L}$ (normal 28 to $96 \mathrm{U} / \mathrm{L}$ ) and total bilirubin $5.1 \mu \mathrm{mol} / \mathrm{L}$ (normal 5.1 to $17 \mu \mathrm{mol} / \mathrm{L})$. Her serum calcium concentration was $3.64 \mu \mathrm{mol} / \mathrm{L}$ (normal 2.25 to $2.62 \mu \mathrm{mol} / \mathrm{L}$ ), and her albumin concentration was $35 \mathrm{~g} / \mathrm{L}$ (normal 30 to $50 \mathrm{~g} / \mathrm{L}$ ). Her alpha-fetoprotein concentration was $38.1 \mathrm{ng} / \mathrm{mL}$ (normal 0 to $8.7 \mathrm{ng} / \mathrm{L}$ ). Serum protein electrophoresis was negative for multiple myeloma.

The patient was managed with intravenous saline hydration, and intravenous pamidronate $90 \mathrm{mg}$ given over $24 \mathrm{~h}$

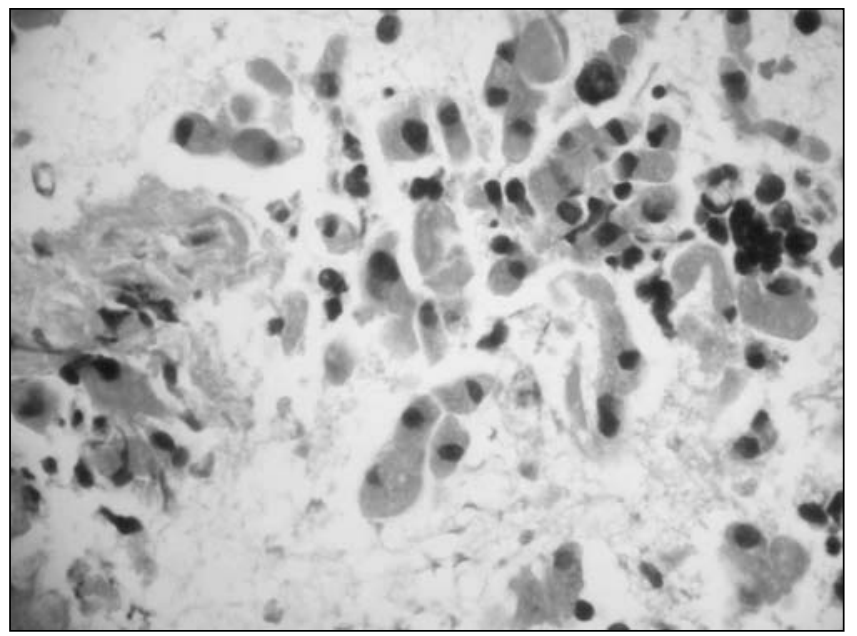

Figure 1) Liver biopsy showing abundant granular cytoplasm, nuclear overlapping with increased nuclear to cytoplasmic ratio and irregular nuclear spacing, consistent with a well differentiated hepatocellular carcinoma

with a good response and improvement in her clinical complaints.

Computed tomography of the abdomen revealed a large heterogeneous hepatic mass measuring $9 \times 11 \times 10 \mathrm{~cm}$. No ascites, portal vein thrombosis or varices were detected. Other than left renal cysts, no other radiographic abnormalities were identified. Colonoscopy was performed and showed only benign colonic polyps and sigmoid diverticulosis. A bone scan was negative for metastasis or fractures. An upper endoscopy was remarkable only for some erosive gastritis. A computed axial tomography scan-guided fine needle aspiration was performed, and the pathological specimen was consistent with a well-differentiated hepatocellular carcinoma and no cirrhosis (Figure 1). The patient was started on chemotherapy with 5-fluorouracil and was discharged home with a serum calcium concentration of $3.66 \mu \mathrm{mol} / \mathrm{L}$ and an oncological follow-up. She returned with similar complaints two months later and with a serum calcium concentration of $3.64 \mu \mathrm{mol} / \mathrm{L}$. At this stage, an intact parathyroid hormone (PTH) level was found to be low, at $8 \mathrm{pg} / \mathrm{mL}$ (normal 15 to $65 \mathrm{pg} / \mathrm{mL}$ ). Her 1,25-dihydroxyvitamin $\mathrm{D}$ concentration was $41 \mathrm{pg} / \mathrm{mL}$ (normal 15 to $60 \mathrm{pg} / \mathrm{mL}$ ), and her 25-hydroxyvitamin D concentration was $7 \mathrm{ng} / \mathrm{mL}$ (normal 9 to $52 \mathrm{ng} / \mathrm{mL}$ ). Her PTH-related peptide (PTH-rP) concentration was elevated, at $5.2 \mathrm{pmol} / \mathrm{L}$ (normal less than $1.3 \mathrm{pmol} / \mathrm{L}$ ). The patient's condition remained stable with regular oncological follow-up.

\section{DISCUSSION}

The most common causes of hypercalcemia are primary hyperparathyroidism and malignancy (13). Hypercalcemia of malignancy occurs most commonly with solid tumours, especially squamous cell malignancy of any origin, and breast and renal cell carcinoma (3). In these situations, a humoral secretion of PTHrP has been implicated as the most likely etiology, while the intact PTH is usually sup- 
pressed (14). Because this condition may occasionally mimic hyperparathyroidism, a PTH level is commonly required for the diagnosis. Other tumours can cause hypercalcemia, namely multiple myeloma, in which direct bone resorption is triggered by a cytokine secreted from myeloma cells, and lymphoma, in which hypercalcemia is believed to be secondary to an osteolytic process or to the formation of 1,25-dihydroxyvitamin $\mathrm{D}$. As yet, metastatic cancer is believed to be the most common cause of hypercalcemia of malignancy (13).

The association between hypercalcemia and hepatic malignancy is rare, with a prevalence ranging from $1.5 \%$ to $40 \%$ in different reports $(3,12)$. It was suggested that the inclusion or exclusion of patients with documented metastasis might have accounted for this big variation. Hypercalcemia has been described mainly with hepatocellular carcinoma and cholangiocarcinoma (3). A distinct histological subtype called 'sclerosing hepatic carcinoma' has been strongly linked to hypercalcemia in the absence of bony metastasis $(10,12)$.

The mechanism of hypercalcemia in patients with primary hepatic malignancy, in the absence of metastasis, is believed to be most commonly associated with the secretion of a PTHrP from malignant cells. This intrinsic secretion theory was supported by the fact that hypercalcemia

\section{REFERENCES}

1. Bergsland EK, Venook AP. Hepatocellular carcinoma. Curr Opin Oncol 2000;12:357-61.

2. Wands JR, Blum HE. Hepatocellular carcinoma. N Engl J Med 1991;325:729-32.

3. Oldenburg WA, Van Heerden JA, Sizemore GW. Hypercalcemia and primary hepatic tumors. Arch Surg 1982;117:1363-6.

4. Ince $N$, Wands JR. The increasing incidence of hepatocellular carcinoma. N Engl J Med 1999;340:798-9.

5. Chalasani N, Horlander JC Sr, Said A, et al. Screening for hepatocellular carcinoma in patients with advanced cirrhosis. Am J Gastroenterol 1999;94:2988-93.

6. Choudhary AM, Roberts I, Gupta T. Changing patterns of hepatocellular carcinoma. Am J Gastroenterol 1999;94:2571-2.

7. Chalasani N, Said A, Ness R, et al. Screening for

hepatocellular carcinoma in patients with cirrhosis in the United States: results of a national survey. Am J Gastroenterol 1999;94:2224-9. has been treated successfully by tumour resection or embolization $(3,12)$. In our patient, the absence of bony metastasis, corroborated by a suppressed PTH and an elevated PTHrP, support this belief, yet the worsening of her hypercalcemia shortly after therapeutic chemotherapy is puzzling. The concomitant secretion of other factors, such as tumour necrosis factor triggered by chemotherapy, may provide an explanation.

Other endogenously secreted mediators, however, have been postulated, including transformin growth factor alpha, interleukin-1-alpha, tumour necrosis factor, prostaglandin E and 1,25 dihydroxyvitamin $\mathrm{D}(11,14)$.

The mainstay of therapy for hypercalcemia of malignancy is similar to that of hypercalcemia of a nonmalignant origin. It involves mainly correction of dehydration, institution of saline diuresis to increase calcium excretion through the glomeruli and the use of agents known to decrease bone resorption, namely the biphosphonate pamidronate, which usually requires four days for complete action (13).

Although a compounded etiological relationship between hypercalcemia and primary hepatic malignancy remains to be solved, we believe that it is important not to overlook this association as a potential primary key to the diagnosis of these cancers.

8. Sangiovanni A, Colombo E, Radaelli F, et al. Hepatocyte proliferation and risk of hepatocellular carcinoma in cirrhotic patients. Am J Gastroenterol 2001;96:1575-80.

9. Ulmer SC. Hepatocellular carcinoma. A concise guide to its status and management. Postgrad Med 2000;107:117-23.

10. Szilagyi A, Alpert L. Clinical and histopathological variations in hepatocellular carcinoma. Am J Gastroenterol 1995;90:15-23.

11. Ikeda T, Tozuka S, Hasumura Y, et al. Prostaglandin-E-producing hepatocellular carcinoma with hypercalcemia. Cancer 1998;61:1813-4.

12. Attali P, Houssin D, Roche A. Hepatic arterial embolization for malignant hypercalcemia in hepatocellular carcinoma. Dig Dis Sci 1984;29:446-9.

13. Mundy GR, Guise TA. Hypercalcemia of malignancy. Am J Med 1998;105:84-5.

14. Tamura K, Kubota K, Take H, et al. Parathyroid hormone-related peptide as a possible cause of hypercalcemia in a hepatocellular carcinoma patient. Am J Gastroenterol 1994;89:644-5. 


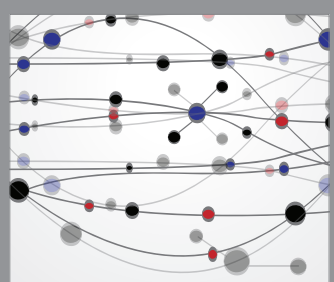

The Scientific World Journal
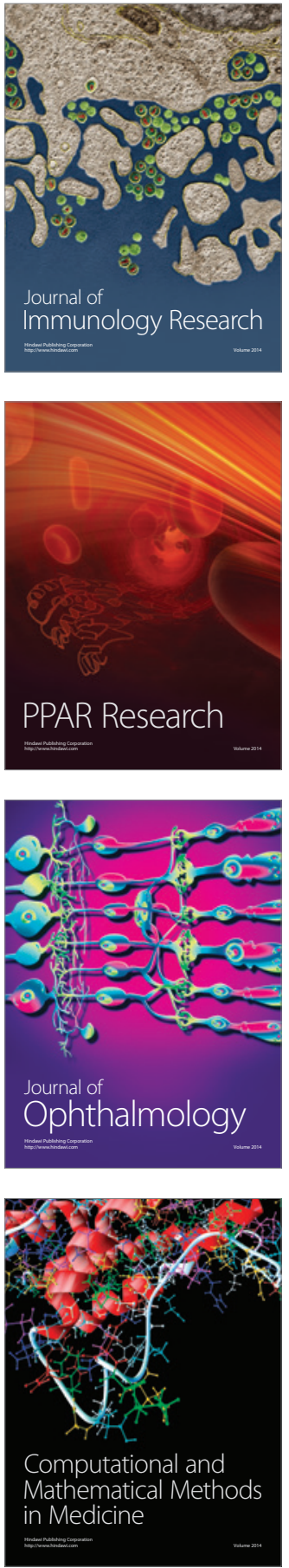

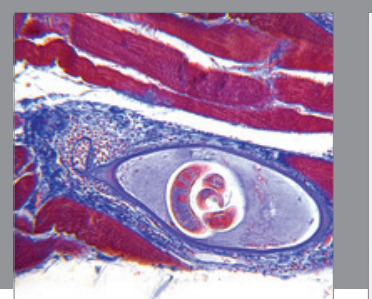

Gastroenterology Research and Practice

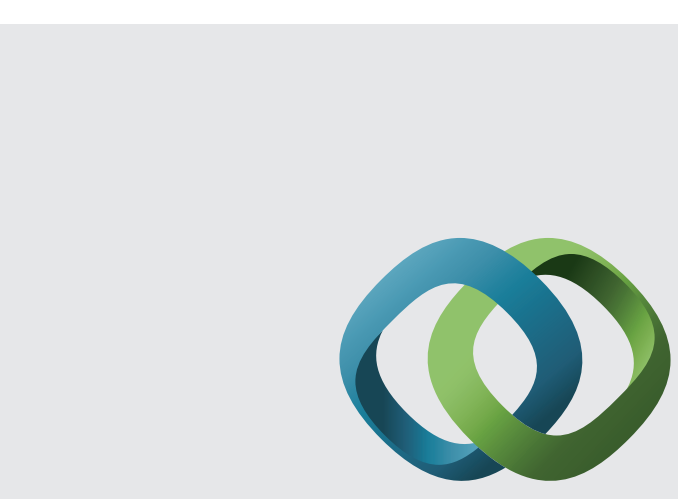

\section{Hindawi}

Submit your manuscripts at

http://www.hindawi.com
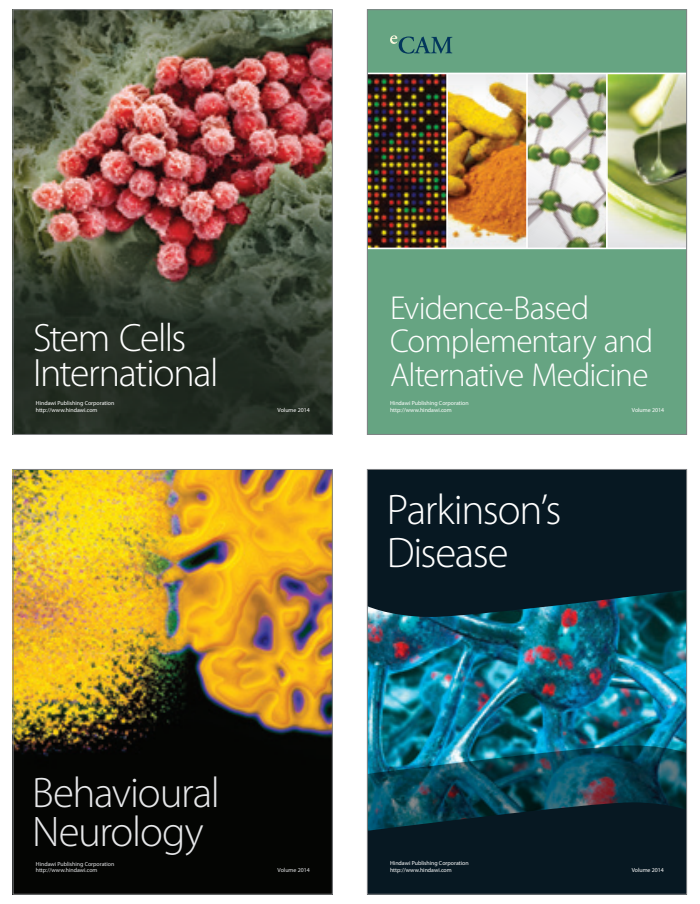
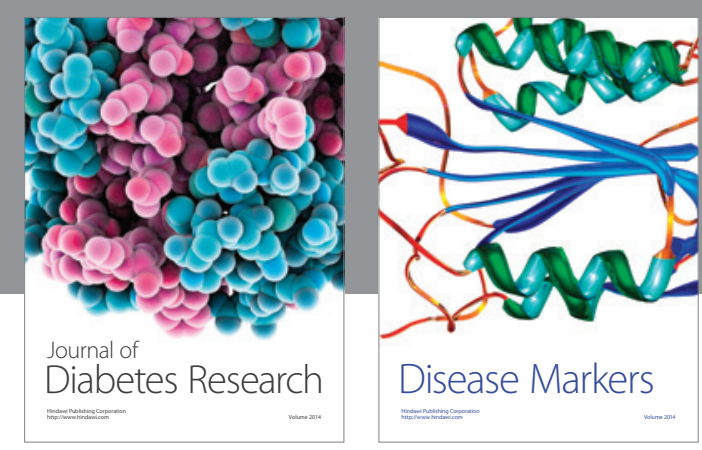

Disease Markers
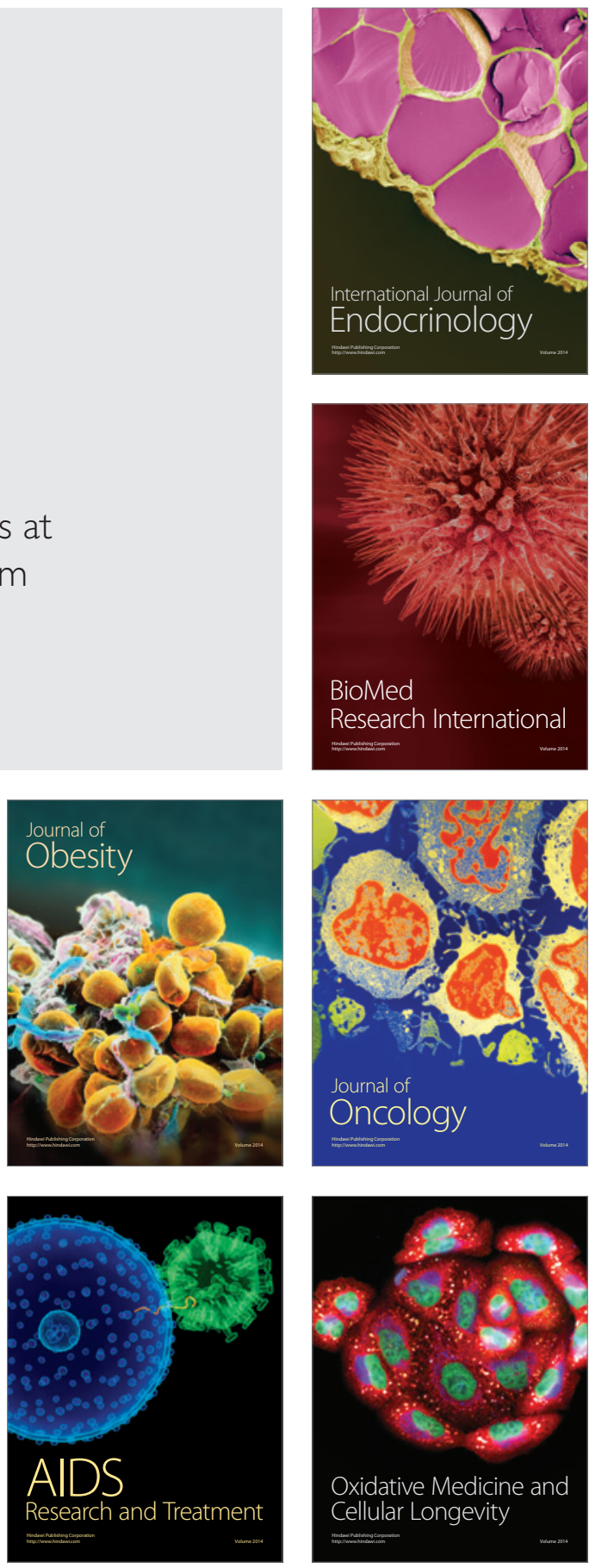